\title{
身長の発育現象にみられる地域差・性差
}

\author{
徳 永 幹 雄* 藤 本 実 雄* \\ （昭和47年 1月21日受付）
}

\section{Regional and Sex Differences on the Phenomenon of Growth in Height}

\author{
M. Tokunaga and J. Fujimoto (Kyusyu University)
}

この研究の目的は農山漁村の児童飞ついて身長の発育曲線と発育速度曲線の地域差・性差を明らかれすること であった. おるな結果はつぎのと扣りである.

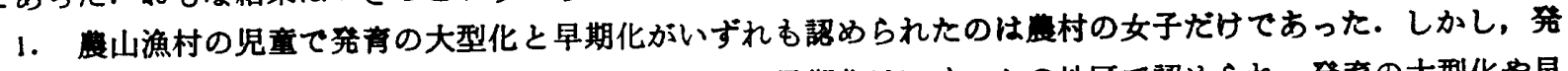
育の大型化は他の地区では認められなかったか，発育の早期化はいくつかの地区で認められ，発育の大型化や早 期化飞対して特有の地域差・性差があった。

2. 農村と漁村の児童はほぼ同し時期飞発有速度曲線のピークが認められたが，山村の児童はこれらより1年 逑く発有速度に地域差が認められた。 また，農山漁村とす女子が $2 \sim 3$ 年早く発育速度曲線のピークが現われ， 男女間に顕著な差が認められた。

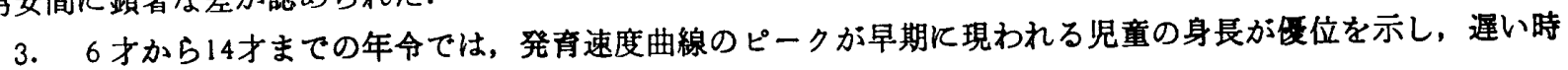
期にピークを示す児童の身長は劣位を示した.

The purpose of this study was to make clear the regional and sex differences on the growth curves and the growth velocity curves in height. The subjects were boys and girls in a rural district (Hatae), a mountain village (Gokanosyo) and fishing villages (Oshima and Genkai). These subjects were measured longitudinally from 10 to 14 years old. The first study was carried out from 1956 to 1960 and the second from 1964 to 1968.

The main results obtained were as follows:

1. Girls in the rural district grew significantly taller in height. Girls in the rural district and fishing villages and boys in fishing village (Genkai) grew earlier to the peak of growth velocity curve in height.

2. In the second study, for boys in the rural district and fishing villages, the peak of the growth velocity curve in height was between about 12 and 13 years old and for girls, was between 9 and 10 .

But, boys in mountain village were between 13 and 14 years old, and girls were between 10 and 11. On the sex differences, girls in the four areas showed 2-to 3-years earlier peak in the growth velocity curve of height than boys.

3. It was found that the growth curve in height from 6 to 14 years old of boys and girls who had an earlier peak in the growth velocity curve was superior to boys and girls who had later peak.

(M. Tokunaga and J. Fujimoto: Regional and Sex Differences on the Phenomenon of Growth in Height, Research Journal of Physical Education, Vol. 17, No. 2, September, 1972, pp. 75 80).

* 九州大学教举部 
落

身体発育の加速化現象憕育の早熟化, 早期化 (促進化)，大型化（巨大化）の諸現象が内包され ているといわれている1．われわれは昭和 31 年か ら発育の加速化現象を分析する目的から都市と農 村漁村の形態発青と運動能力の発達について第 1 次 5 年研究，第 2 次 5 年研究のもとで同一児童を 5 年間継続して測定してきた。 そして，岡部・他 $(1969)^{2)}$, 藤本・他 $(1969)^{8)}$, 藤本 $(1970)^{1)}$ は都 市の児童に身体発育の大型化と早期化が認められ ることを報告した。

今回は，農山漁村に和ける児童の身長の発育に つい,

1. 発育の大型化と早期化の地域差・性差

2. 発育速度の地域差・性差

3. 発育速度曲線による発育パターンと発育曲線 の関係

の 3 点について分析した.

\section{方法}

第 1 次 5 年研究 (昭和 $31 \sim 35$ 年, 以後 1 次研究 と呼5)，第 2 次 5 年研究 (昭和39年〜 43年, 以後 2 次研究と呼ふ）ともまったく同様の計面のすと で形䔮発育と運動能力の発達について10才（小学 5 年）を起点に 14才（中学 3 年）まで継続して測 定した．今回は身長の発育について分析する，標 本地区と 2 次研究にお゙ける標本の大きさはつぎの とおりである。

農村, 福岡県系島郡波多江地区, 男子32名(29), 女子23名 (23).

山村, 熊本県八代郡五家荘地区および 熊本県球 磨郡五木村地区，男子27名 (13)，女子34 名 (16).

離島漁村, 福岡県宗像郡大島町地区, 男子19名, 女子 22 名.

離島漁村, 福岡市玄界町地区, 男子18名 (17), 女子 8 名 (8).

なお，6才から 9才までの資料は小学校保存の 身体検査海から引用し（）内はその祭本の大き さを示している．また，漁村（大島）のこの期間 の資料はなかった。

\section{耛果と考察}

1. 発育の大型化と早期化の地域差・性差

1 次研究と 2 次研究深拈ける鸟長の年令別平均 值から同一地区ごとに発有曲線を示すと図 1 のと おりである．ここでの発有の大型化とは同一地区 において前時代（1 次研究）の児童と後時代 (2 次研究）の児童の身長の平均值が，それぞれ対応 する年令で統計的に有意に増加していることから 考察する.

結果は男子では農山漁村ともわずかに增加は認 められるが有意な差ではなかった，女子では農村 の $10 ， 11 ， 12 ， 13 ， 14$ 才時に $1 \%$ 水準で，山村の 13才時に $5 \%$ 水準で有意に 增加していることが認 められた。すなわち，農山漁村における発育の大 型化は農村の女子たけに顕著に認められたことと なる。

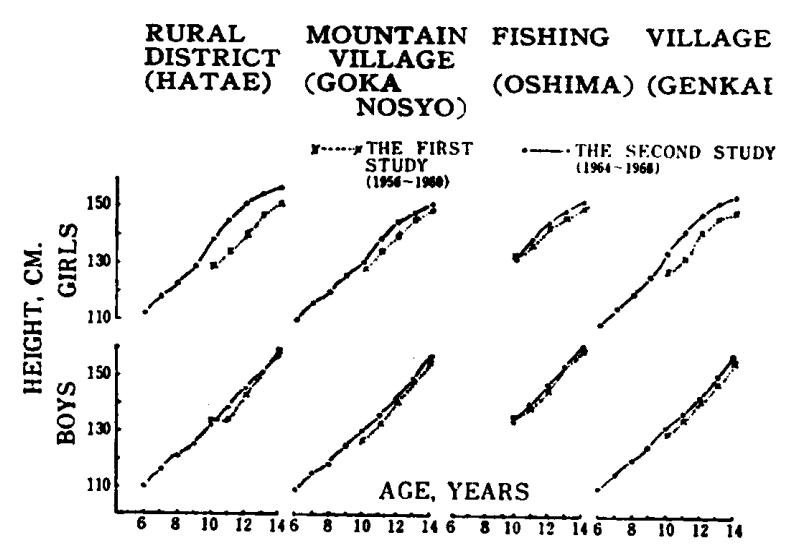

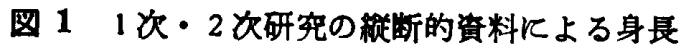
の発育曲線

つぎに, 発育の早期化についてみた，1次・2 次研究に打ける身長の年間発育增加量の平均值を グラフに示すと発育速度曲線が図 2 のように描か れる. 発育の早期化は同一地区の前時代の発育速 度曲線のピークが後時代のピークょり早くなるこ とから考察することができる。

結果は，辳村の女子で 3 年早く，漁村（玄界） の女子で 2 年早くピークを示し発育の早期化が認 められた。 また，漁村（大島）の女子と漁村（玄 界）の男子は前者は 2 次研究，後者は 1 次研究の ピークが明らかでないが，発育速度曲線のカーブ から発育の早期化が推察される。逆に，発育の早 期化が認められないのは農村の男子，漁村（大島） 


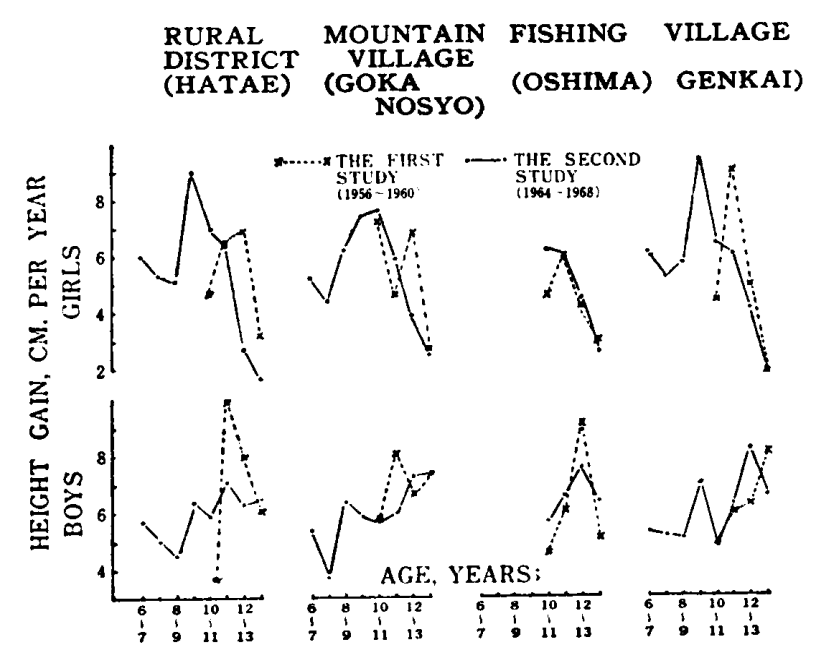

図 21 次・2 次研究の緥断的資料による身長 の発育速度曲線

の男子および山村の男女で 1 次・2 次研究ともピ 一クは同年令を示している．ただ，山村の男子だ けは1次研究のピークが11〜12才時に対して2次 研究では14才以降へとピークが遅くなっている。 しかし，このことは1次研究のピークも14才以降 にあるとも考劣られるので結論はできない。

以上，発育の大型化と早期化についてみてきた が，わが国の児童の発育は猪飼・高石 (1968) ${ }^{4}$, 朝比奈 $(1971)^{5)}$, 船川 (1971) な2 な゙多くの研究者 がここ数10年の間に発育の大型化と早期化が認め られることを報告している，また，今回と同時に 测定した都市（福岡市姪の浜地区）の男女にも発 育の大型化と早期化が認められている ${ }^{1) .22 .3)}$ 。 し たがって，今回の農山漁村では農村の女子だけが これらの資料と同㥞に発育の大型化と早期化が認 められ，同じ発育傾向を示していることがわかる。 つぎに，発有の大型化は農村の女子以外では認め られなかったが，発育の早期化は漁村（大島・玄 界) の女子や漁村 (玄界) の男子でも認められ, 山村の男女には認められなかったことなどから発 裔の大型化や早期化に対して特有の地域差, 性差 があることが明らかにされたものと思われる、ま た，発育の大型化と早期化の関係をみると，大型化

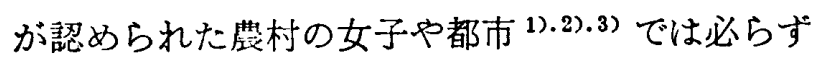
早期化が認められているが，たと早期化が認め られても必らずしも大型化を示さない地区もあっ た。さらには，早期化が認められない地区では大 型化は認められない.このことは, 多くの研究

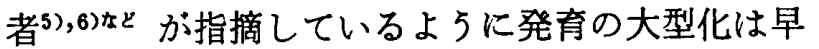
期化に起因していることを明らかにしたものと推 察することができる。

\section{2. 発育速度の地域差・性差}

図 2 の 2 次研究に打ける発育速度曲線から発育 のピークを求め, 発有速度の地域差・性差をみた。 地域差では男子は農村が 11〜12才時にピークを示 乙最も早く，漁村（大島・玄界）は12〜13才時, 山村は最す遅く 13〜14才時以降である. 女子では 農村と漁村 (玄界) が9〜10才時で早く, 山村は 10〜11才時で遅い，漁村（大島）は10才以前の資 料が不明であるが 9〜10才時にピークを示すので はないかと思われる。

都市の児童について藤本 (1970) ${ }^{1)}$ や藤田 - 他 (1971) ${ }^{7)}$ は男子は 12〜13才時, 女子は 9〜10才時 にピークを示すと報告している。これらと比較す ると農村と漁村 (大島・玄界) では男女ともほぼ 同じピークの時期を示したとみてよいであろ5. しかし，山村だけは男女ともこれらの地区ょり 1 年遅れてピークを示し地域差が認められた。 その 原因として，農村は福岡市の近郊であることや兼 業農家が年々增加し都市化の傾向が認められるこ と，漁村 (大島・玄界)でも離島とはいえ現在は 交通も便利になり都市化の傾向が認められ，栄養 面でも改善されている事情等がある。しかし，熊 本県の山奥であり隔絶された山村だけが交通は便 利になったとはいえ, 都市の周辺地区の農村や漁 村より発育速度が遅れているすのと思われる。

性差では農村で 2 年，山村および漁村（大島・ 玄界）で 3 年，いずれも女子にピークが早く現わ れ顕著な男女差が認められた。

【つぎに，10〜14才間の資料によって発育速度曲 線のパターンを分類した．男女とも同一基準を作 成するため，10〜14才間の個々の年間発育増加量 を男女ともすべて合計した結果，合計した年間発 育增加量の数 732 , 平均値 $5.71 \mathrm{~cm}$, 標準偏差 2.49 $\mathrm{cm}$ を得たので，表1のような発育段階基準を設 け，個々の発育速度曲線のパターンを分類すると 表 2 のとおりである．各発育パターンに属する児 童の発育速度は図 3 のような曲線を描く，最も多 い発育パターンをみると男子では農村は遅い時期 にピークを示す上昇型, 山村は上昇型と凸型, 漁 
变 1 年間発育增加量の 5 段階区分の基準

\begin{tabular}{clc}
\hline Grade & \multicolumn{1}{c}{ Division } & Height Gain, CM. per Year \\
\hline $1:$ & $\mathbf{M}-1.5 \mathrm{~S} \mathrm{D}>\mathbf{X}$ & $\sim 1.9 \mathrm{~cm}$ \\
$2:$ & $\mathrm{M}-1.5 \mathrm{~S} \mathrm{D} \leqq \mathrm{X}<\mathrm{M}-1.5 \mathrm{~S} \mathrm{D}$ & $2.0 \sim 4.4$ \\
$3:$ & $\mathbf{M}-0.5 \mathrm{~S} \mathrm{D} \leqq \mathrm{X}<\mathrm{M}+0.5 \mathrm{~S} \mathrm{D}$ & $4.5 \sim 6.9$ \\
$4:$ & $\mathbf{M}-0.5 \mathrm{~S} \mathrm{D} \leqq \mathrm{X}<\mathrm{M}+1.5 \mathrm{~S} \mathrm{D}$ & $7.0 \sim 9.4$ \\
$5:$ & $\mathbf{M}-1.5 \mathrm{~S} \mathrm{D} \leqq \mathrm{X}$ & $9.5 \sim$ \\
\hline
\end{tabular}

表 2 発育速度曲線によって分類された発育パターンの出現率 $(\%)$

10〜14才間

\begin{tabular}{|c|c|c|c|c|c|c|c|c|}
\hline \multirow{2}{*}{\multicolumn{2}{|c|}{ Areas }} & \multirow[b]{2}{*}{$\mathbf{N}$} & \multicolumn{6}{|c|}{ Patterns of Growth Velocity Curve } \\
\hline & & & Ascending & Convex & Concave & Descending & Uncanged & Mixed \\
\hline \multicolumn{9}{|c|}{ Boys } \\
\hline Rural District & & 32 & 44 & 25 & 13 & 6 & 9 & 3 \\
\hline Mountain Villa & okanosyo) & 27 & 33 & 33 & 22 & 11 & 0 & 0 \\
\hline Fishing Village & ima) & 19 & 32 & 42 & 11 & 11 & 0 & 5 \\
\hline Fishing Village & kai) & 18 & 39 & 56 & 6 & 0 & 0 & 0 \\
\hline \multicolumn{9}{|l|}{ Girls } \\
\hline Rural District & & 23 & 0 & 13 & 9 & 74 & 4 & 0 \\
\hline Mountain Villa & okanosyo) & 24 & 0 & 15 & 3 & 74 & 6 & 3 \\
\hline Fishing Village & ima) & 22 & 0 & 32 & 0 & 64 & 5 & 0 \\
\hline Fishing Village & kai) & 8 & 0 & 25 & 0 & 75 & 0 & 0 \\
\hline Urban District & Boys & 62 & 23 & 58 & 8 & 8 & 2 & 2 \\
\hline (Meinohama) & Girls & 30 & 3 & 23 & 0 & 77 & 0 & 0 \\
\hline
\end{tabular}

（注）パターンの分類は，例えは，年間発育增加典の段階点が $5-4-3-2$ は下降型，2-3 ー4ー2は凸型とした. 都市は参考に示した.

表 3 発青速度曲線のピークの出現率 $(\%)$

6〜14才間

\begin{tabular}{|c|c|c|c|c|c|c|c|c|c|c|}
\hline \multirow{2}{*}{\multicolumn{2}{|c|}{ Areas }} & \multirow[b]{2}{*}{$\mathbf{N}$} & \multicolumn{8}{|c|}{ Peaks of Growth Velocity Curve } \\
\hline & & & $\begin{array}{l}6 \\
? \\
7\end{array}$ & $\begin{array}{l}7 \\
8 \\
8\end{array}$ & $\begin{array}{l}8 \\
9 \\
9\end{array}$ & $\begin{array}{c}9 \\
1 \\
10 \\
\end{array}$ & $?_{11}^{10}$ & $\begin{array}{c}11 \\
12 \\
\end{array}$ & $\stackrel{12}{13}$ & $\begin{array}{l}13 \\
14 \mathrm{Age}\end{array}$ \\
\hline \multicolumn{11}{|c|}{ Boys } \\
\hline \multicolumn{2}{|c|}{ Rural District (Hatae) } & 29 & 7 & 0 & 0 & 14 & 3 & 28 & 7 & $4 !$ \\
\hline \multicolumn{2}{|c|}{ Mountain Village (Gokanosyo) } & 13 & 0 & 0 & 0 & 0 & 0 & 15 & 54 & 31 \\
\hline \multicolumn{2}{|c|}{ Fishing Village (Genkai) } & 17 & 0 & 0 & 0 & 18 & 0 & 18 & 41 & 24 \\
\hline \multicolumn{11}{|c|}{ Girls } \\
\hline \multicolumn{2}{|c|}{ Rural District (Hatae) } & 23 & 0 & 0 & 0 & 78 & 0 & 22 & 0 & 0 \\
\hline \multicolumn{2}{|c|}{ Mountain Village (Gokanosyo) } & 16 & 0 & 0 & 0 & 38 & 44 & 13 & 6 & 0 \\
\hline \multicolumn{2}{|c|}{ Fishing Village (Genkai) } & 8 & 0 & 0 & 0 & 100 & 0 & 0 & 0 & 0 \\
\hline Urban District & Boys & 60 & 0 & 0 & 0 & 0 & 7 & 25 & 50 & 27 \\
\hline (Meinohama) & Girls & 32 & 0 & 0 & 3 & 39 & 26 & 29 & 0 & 3 \\
\hline
\end{tabular}

（注）都市の料は参教に示した。 


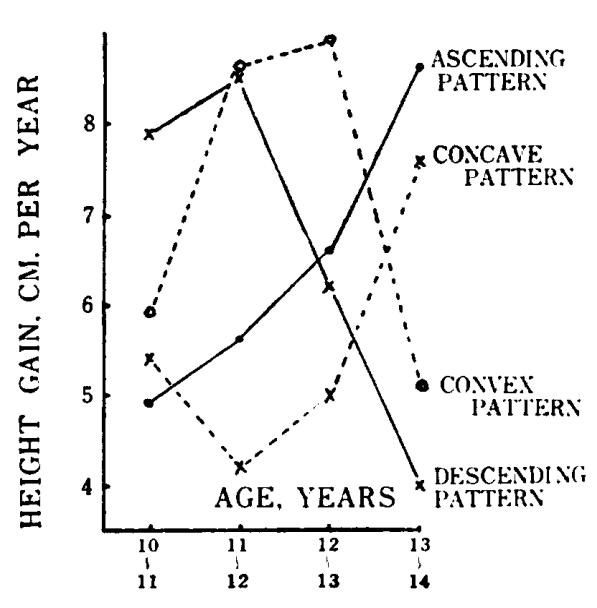

図 3 各無帮パターンの発青速度曲線

村（大寓・玄界）は凸型である，女子では震山漁 村とも早期にピークを示す下降型が最も多く大半 を占めている。

さらに，女子は発有速度曲線のピークが 10才以 前を示すので，6才からの資料を付加し 6〜14才 間の資料の完全な男女について個々の発育速度曲 線のピークを求めた．結果は表 3 のとおりであ る.最も多いピークは男子では農村は13〜14才時, 山村と漁村（玄界）は12〜13才時，女子では農村 と漁村 (玄界) は 9 10才時, 山村は10〜11才時 であった。ささに，年間発育增加量の平均值から 発育速度曲線のピークをみた時, 農村の男子は11 〜12才時にピークを示した。 しかし，表 2 で上昇 型が多いこと，表 3で13〜14才時にピークを示す 児童が多いことなどから，農村地区の男子は，む しろ，個人差の大きい結果であろ5と思われる。

こ5した個人差の傾向は山村の男子であみられ る. 緥断的測定資料の特徵は個々の発有速度曲線 が分析できることにある. 今回のよ5に測定值を 平均化した時の結果に個人差が存在することを見 逃してはならない，そうした点からみると，身体 発育の分析には縦断的資料による個々の発育速度 曲線の分析が必要であることも付言しておかなけ ればならない。

3. 発育速度曲線による発育パターンと発青曲 線の関係

10〜14才間の発育速度曲線によって分類された 上昇型，凸型，凹型，下降型の 4 つの発育パター ンに属する児童の身長の発育曲線を 6 才までさか のぼってみると园4のと和りである，男子では下
降型は10〜14才間で最も優位を示し，凹型は 6〜 14才間で最も劣位を示した。その中間に凸型と上 昇型が位置している．女子でも下降型と上昇型で あるが男子と同じ傾向を示した。 小宮 $(1971)^{8)}$ は 都市の児童について10〜14才間で同じ結果を得て いるので，少なくとも6才から14才までの年令で は発育速度曲線のピークが早期に現われる览童の 身長が優位を示し，遅い時期に現われる児童の身 長は劣位を示すすのと思われる. しかし，14才の 時点では男女とも下降型と凸型の発育曲線は接近 しておりこれらのパターンの曲線が今後どのよ うに推移するかは追跡測定に待たなければならな い.

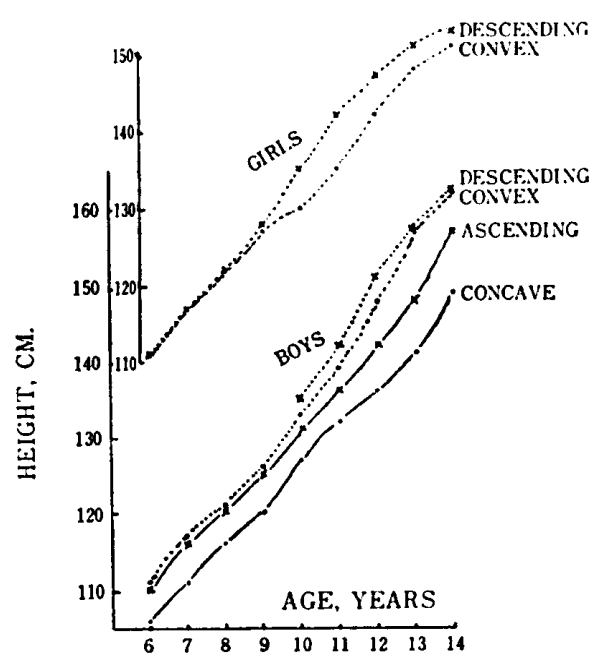

図 4 各発育パターンの発育曲線

\section{要約}

福岡県, 熊本県の農山漁村の 4 つの地区の児童 について身長の発育現象を分析した結果は，つぎ のように要約することができる.

1. 農山漁村の児童で発育の大型化と早期化が いずれも認められたのは農村の女子だけであっ た。しかし，発育の大型化は他の地区では認めら れなかったが，発育の早期化はいくつかの地区で 認められ，発育の大型化や早期化に対して特有の 地域差，性差があることが明らかにされた。 た，発育の大型化は発育の早期化に起因している ことが推察された。

2. 㖘村と漁村の児童はほぼ同じ時期に 発育速 度曲線のピークが認められたが，山村の児童はこ 
れらより 1 年遅くピークが現われ発育速度に地域 差が認められた。 また，農山漁村とも女子が 2 亿 3 年早く発育速度曲線のピークが現われ男女間に 顕著な差が認められた。発育速度曲線のパターン を分類した結果，身体発育の分析法楈断的資料 による個々の発育速度曲線の分析方必要であるこ とが示唆された。

3，6才から14才までの年令では発青速度曲線 のピークが早期に見われる児童の身長が優位を示 し，遅い時期にピークが現われる児童の身長は劣 位を示すことが認められた。

\section{考文献}

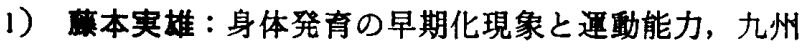
大学体育学研究, 4(3), 23 24, 1970.

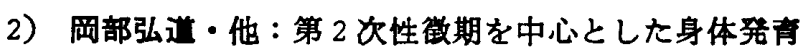
と運動能力の発達住関する研究一第 5 報一, 九州大学 体育学研究, 4(2), 1 10, 1969.

3）藤本実雄 - 他：身体発育と運動能力について，九州 大学体育学研究, 4(2), 11 22, 1969.

4）猪飼道夫・高石甼弘：身体発育之教育，318～321， 第一法規, 1968.

5）朝比奈一男：発育の促進化現象とは何か, 体育の科 学, $21(7), 421 \sim 425,1971$.

6）船川筃夫：形態にあらわれた発育促進現象，体育の 科学, $21(7), 432 \sim 437,1971$.

7）藤田一郎 - 他: 形態発育の綐断的研究, 日本体育学 会第22回大会号, 540,1971.

8）小宮秀一：少年期における身体养育の Pattern と 荤動能力の発迲について, 体育学研究, 16(2), 75〜 84, 1971 . 